\title{
JOINT AND NEUROMUSCULAR MANIFESTATIONS OF PERIARTERITIS NODOSA
}

\author{
BY \\ EDWARD W. LOWMAN \\ New York City, N.Y.
}

(RECEIVED FOR PUBLICATION MARCH 31, 1952)

Periarteritis nodosa is a protean disease which may manifest itself in multiple systems of the body. Muscle soreness and arthralgias are common early components of the disease complex, but indications are that frank joint reactions are infrequent and arthritis rare.

In an effort to clarify the status of joint and of neuromuscular manifestations in periarteritis, the records of 43 patients who died of the disease have been reviewed. In each case the diagnosis was proven by post-mortem examination, and in one changes in the synovial tissue were studied histologically.

Periarteritis nodosa is a pan-vasculitis (Dunbar, 1936; Spiegel, 1936) producing greatest damage on the arterial side of the circulatory system. It involves arteries, arterioles, capillaries, and veins, the greatest damage occurring in the smaller arteries and arterioles. The initial phase is one of acute damage with oedema and necrosis; this usually affects the media first, and then spreads to the other coats and beyond to contiguous perivascular tissue. This acute phase of damage and destruction is followed by a reparative or granulation stage which finally heals by fibrosis. As a result of the inflammatory process compromising the calibre of the blood vessels, tissue distal to and normally dependent upon them for nourishment suffers from ischaemia. The degree of ischaemia depends upon the degree of vascular embarrassment and the availability of collateral circulation; it may vary from transient ischaemia to frank infarction. The involved vessel may develop thrombosis, aneurysm, or a rupture resulting in local haemorrhage (Diaz-Rivera and Miller, 1946).

Any organ of the body may be involved; these are, in order of frequency, kidneys, heart, liver, gastro-intestinal tract, mesenteric arteries, muscles, spleen, lungs, and peripheral and central nervous system. Curtis and Coffey (1934) classified the disease into six types occurring singly or in combination: gastro-intestinal, renal, neuro-muscular, cardiac, cerebral, and cutaneous.

The aetiology of the disease is not established. Many investigators, including Spiegel (1936), Boyd (1938), and Friedberg and Gross (1934), have noted the high incidence of rheumatic fever in patients developing periarteritis nodosa and have considered this significant. The experimental work of Rich (1942) and of Rich and Gregory (1943) in producing lesions in rabbits resembling those of periarteritis nodosa by hypersensitivity reaction with horse serum stimulated much interest in the allergic potentialities in the aetiology of this disease. It is felt by many (Spiegel, 1936; Cohen and others, 1936; Keefer, 1943) that it is of allergic 
origin and that the vascular lesions result from a severe allergic reaction, giving rise to damage to the responding vascular system. Cohen and others (1936) think that anyone suffering from an allergy is a potential victim of periarteritis nodosa.

Neuromuscular and joint symptoms are common early manifestations of periarteritis nodosa. The neuromuscular changes are consequent upon the localization of the destructive vascular lesions in vessels supplying the muscles or the nerves of the muscles. Ischaemia resulting from the arterial embarrassment produces either a myositis with localized tenderness or a neuritis of the mono- or polyneuritis type. These may be minimal or may be present as the predominant features of the disease. Objectively, there may be tenderness along one or more peripheral nerves, or there may be only localized areas of muscle tenderness with or without palpable tender nodules. Typically the tenderness is aggravated by activity or by palpation and improves with rest. Weakness may be a subjective manifestation of aesthenia or, in the case of peripheral neuritis, may represent a true motor nerve impairment and any degree of paralysis may develop.

TABLE I

JOINT INVOLVEMENT IN PERIARTERITIS NODOSA

\begin{tabular}{|c|c|c|c|c|c|c|c|}
\hline \multirow{3}{*}{\multicolumn{2}{|c|}{ Author }} & \multirow{3}{*}{ Date } & \multirow{3}{*}{$\begin{array}{c}\text { Total } \\
\text { Patients }\end{array}$} & \multicolumn{4}{|c|}{ Patients reporting Prodromal Joint Symptoms } \\
\hline & & & & \multicolumn{2}{|c|}{ One Joint } & \multicolumn{2}{|c|}{ More than One Joint } \\
\hline & & & & No. & $\%$ & No. & $\%$ \\
\hline $\begin{array}{l}\text { Boyd } \\
\text { Spiegel } \\
\text { Jones } \\
\text { Diaz-Riv } \\
\text { Harris, L }\end{array}$ & 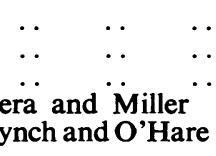 & $\begin{array}{l}1938 \\
1936 \\
1942 \\
1946 \\
1939\end{array}$ & $\begin{array}{r}100 \\
17 \\
14 \\
7 \\
6\end{array}$ & $\begin{array}{r}27 \\
5\end{array}$ & $\begin{array}{l}27 \\
29\end{array}$ & $\begin{array}{l}9 \\
1 \\
3\end{array}$ & $\begin{array}{l}64 \\
14 \\
50\end{array}$ \\
\hline Lowman & . & 1952 & 43 & & & 30 & 70 \\
\hline
\end{tabular}

The neuromuscular findings are frequent and helpful diagnostic clues in the disease, but the joint manifestations are more diverse and unreliable, and clinical and pathological data on these are sparse. There is a division of opinion as to the relative incidence of demonstrable mono- or polyarthritis (Table I). Boyd $(1940 \mathrm{a}, \mathrm{b})$ found that polyarthritis with involvement of large joints or of all joints was very common; the joint symptoms in his cases, however, tended to fade into the background as the syndrome developed in its involvement of other systems. He states that, in his 100 cases, joints were the first system to be involved in nineteen and the second in eight (total, 27 per cent.), but he does not indicate whether this involvement was demonstrable as a synovitis or whether it was a subjective arthralgia. In the fourteen cases described by Jones (1942) the incidence of pain and/or joint swelling was 64 per cent. Spiegel (1936) reported articular prodromal symptoms in five of her seventeen cases, but again did not indicate whether there was any demonstrable synovial reaction. Articular swelling was noted in only four out of 29 new cases reported by Hench and others (1941). 
Vining (1938) reported a case of periarteritis nodosa in a 7-year-old child in whom the initial onset was with joint swelling subsequent to acute tonsillitis; this patient was treated as a case of " acute rheumatism " for months before a biopsy diagnosis of periarteritis nodosa was established. Vining writes:

From time to time there was swelling about several joints but this was thought due to nodal erythematous formation about the joint rather than synovitis.

Flexion deformities of arms and of shoulders did occur, however, in the course of 17 months.

In one of seven cases reported by Diaz-Rivera and Miller (1946) there was pain and soreness of one month's duration in the elbow, shoulder, and knee, as well as in the calf muscles.

A 15-year-old patient (Dunbar, 1936) presented with pain and swelling in both ankles with some increase in local heat, and was treated at first as a case of rheumatic fever before the establishment of a diagnosis of periarteritis nodosa.

A patient described by Carr (1930) had swelling of the knees, together with muscle pains in the feet and legs; the swelling, however, promptly subsided with bed rest and no mention is made of the objective state of the synovial tissue.

Weir (1939) reported a 30-year-old female patient with redness, swelling, stiffness, and pain in the elbows and wrists for 3 days before admission to hospital. Examination showed slight stiffness, tenderness, and pain on motion of the wrists, and "slight swelling" on the dorsal aspects; motion in the elbows was painful and these joints could not be fully extended. Again there is no indication of the amount of actual joint swelling.

In three of their six cases, Harris, Lynch, and O'Hare (1939) noted joint symptoms; one case presenting an acute migratory polyarthritis was treated with typhoid shots and uitimately recovered.

Moschowitz (1938) reports a patient with transient pains in the feet, who was at first diagnosed and treated as a case of arthritis before subsequent developments and biopsy proved periarteritis nodosa.

In the case reported by Curtis and Coffey (1934) there was a 6 months' period of weakness with swelling and pain in the ankles and feet; rest in bed relieved the swelling but not the pain. The swelling was attributed to oedema and the pain to neuritic involvement.

Only scattered cases have been reported wherein demonstrable evidence of synovial and joint changes have been noted. One patient (Hench and others, 1940) had marked articular changes and subcutaneous nodules resembling those of atrophic arthritis, and two others had atrophic arthritis; in all three instances periarteritis nodosa was proved at autopsy.

Investigations of pathological synovial changes in periarteritis nodosa have been even less frequent than clinical reports of joint manifestations. Bauer (1941) observed in one patient a marked synovitis with the typical vascular lesions noted elsewhere in periarteritis nodosa. Keefer (1943) felt that the pathological process was not limited to the vessels, but that granulomatous lesions could also be found in the organs including the joints, bursae, tendon sheaths, and connective tissue. 
Results (Table II)

In thirteen of our 43 cases ( 30 per cent.), there were no symptoms referrable to the muscles, joints, or peripheral nerves.

In thirty cases ( 70 per cent.), muscle and joint symptoms were prominent early, but in only four ( 9 per cent.) did joint swelling appear with the joint pain.

In nineteen cases ( 44 per cent.), the muscle and joint symptoms were prodromal to development of a frank peripheral neuritis. In these nineteen cases, the appearance of peripheral neuritis helped to establish a diagnosis of periarteritis. nodosa. In all but one case, sensory disturbances preceded the motor symptoms. These were variously described as a " burning", " dull aching", and " tenderness" of muscles, and involved feet, calves, and arms. Sharp, shooting pains were complained of by nine patients. Paraesthesias, hyperaesthesias, and numbness accompanied them or developed soon after, to be followed by subjective and objective motor weakness. Since the motor weakness was first evaluated subjectively, and since motor examination was not carried out before admission to the hospital, it is not possible to know whether an unrecognized weakness might not have been present from the start with the sensory disturbance. In twelve cases the feet and calves were the first parts to present symptoms of tenderness and pain; in six cases both upper and lower extremities were concurrently affected; and in only one were the upper limbs alone involved. In four cases the initial complaint was of orthostatic swelling in the ankles and lower legs.

In eleven cases (19 per cent.), there was muscle tenderness and arthralgia without subsequent development of peripheral neuritis. In all of these cases death intervened because of other causes (uraemia, pericarditis, cardiac failure, haemorrhage, dehydration, etc.).

TABLE II SUMMARY OF RESULTS

\begin{tabular}{l|r|r|c}
\hline \multicolumn{2}{c|}{ Signs and Symptoms } & No. & Per cent. \\
\hline Muscle and Joint Symptoms & 30 & 70 \\
Joint Swelling.. &.. & 4 & 9 \\
Peripheral Neuritis &.. & 19 & 44 \\
\hline Total Patients &.. & 43 & 100 \\
\hline
\end{tabular}

Arthralgias when present were generally migratory without swelling; in one case pain without swelling persisted in a knee for 10 days. Generally the muscle aching was worse with activity and better with rest. Muscles were tender to palpation, and in two cases a diagnosis of dermato-myositis was entertained and was not disproved until necropsy examination. In only one case out of the entire group were the muscle symptoms suggestive of a fibrositis. The muscle symptoms varied from vague aching in the neck and back to intense pain involving all four extremities and requiring codeine 4-hourly.

In four cases ( 9 per cent.) with joint pain there was objective evidence of neuritis. Three of these subsequently progressed to a peripheral joint swelling early in the disease, and in one additional case there was questionable joint swelling that predominated in the clinical picture.

In one 30-year-old male patient who had had episodes of rheumatic fever at the ages of 8 and 22 years, there was pain initially in the left arm, followed by migratory joint symptoms in feet, hips, left elbow, wrist, and hand, and right big toe (which last, became swollen and sore). Another patient had an initial acute 
polyarthritis with swelling, pain, and "stiffness" of many joints for one month before muscle symptoms of constant aching and diffuse tenderness dominated the clinical picture. A third patient, 10 weeks after an acute sore throat, developed swelling and tenderness of the hand. This swelling persisted for 2 weeks; 4 weeks later he developed fever, abdominal pain, and muscle wasting, and finally died in convulsions.

In a fourth patient who had profound systemic symptoms and peripheral neuropathy, the left knee became painful without objective evidence of synovitis, and this persisted for 10 days before death. The synovia from this case was examined histologically, and vascular lesions were seen identical with those encountered elsewhere (Fig. 1). Involvement was spotty; the synovia histologically showed only a moderate increase in fibroblastic activity, mild oedema, and fibrous thickening (Fig. 2). There was no cellular cuffing of smaller vessels and no cellular inflammatory exudate despite the severe arterial changes.

\section{Comment}

The organic damage resulting from periarteritis nodosa is directly related to the degree of impairment of blood supply to the organ. Since periarteritis nodosa involves the vascular tree spottily, the organic damage is manifested patchily. The degree of ischaemic necrosis (or infarction) resulting in an involved part will largely depend upon the availability of a collateral blood supply; organs supplied by end arteries would be expected to suffer to the greatest degree from vascular involvement. Conversely, in locations of abundant collateral circulation, more extensive vascular damage would be required to cause a similar degree of ischaemia or infarction.

Since the synovial tissue is abundantly supplied with vessels it would be expected that involvement to a demonstrable degree in this tissue would be unusual, and such seems to be the case. While arthralgias are common, extensive synovitis or arthritis are uncommon. The arthralgias probably represent small localized areas of involvement, demonstrable histologically and subjectively but not by gross objective examination of the joint. This differs from the panvasculitis observed in synovia from cases of lupus erythematosus and from the extensive inflammatory synovitis of rheumatoid arthritis. It seems reasonable that in the rare case of periarteritis nodosa there might be extensive enough vascular involvement in the synovia of a joint to produce a more extensive process, but statistically this proves to be infrequent.

Though cases of atrophic arthritis in which periarteritis nodosa was later proved at autopsy have been reported, it 'cannot be assumed that the two conditions were points of the same process; it would be wiser to assume that the two separate disease phenomena co-existed in the same patients.

Oedema of dependent parts seems not uncommon in cases of periarteritis nodosa. The cause of this is unknown unless it be a manifestation of the peripheral neuritis. Soft tissue oedema, together with muscle soreness and tenderness, may prove misleading to one unaccustomed to evaluating synovial reactions in joints, and an erroneous impression of " arthritis " might be entertained. Careful examination 


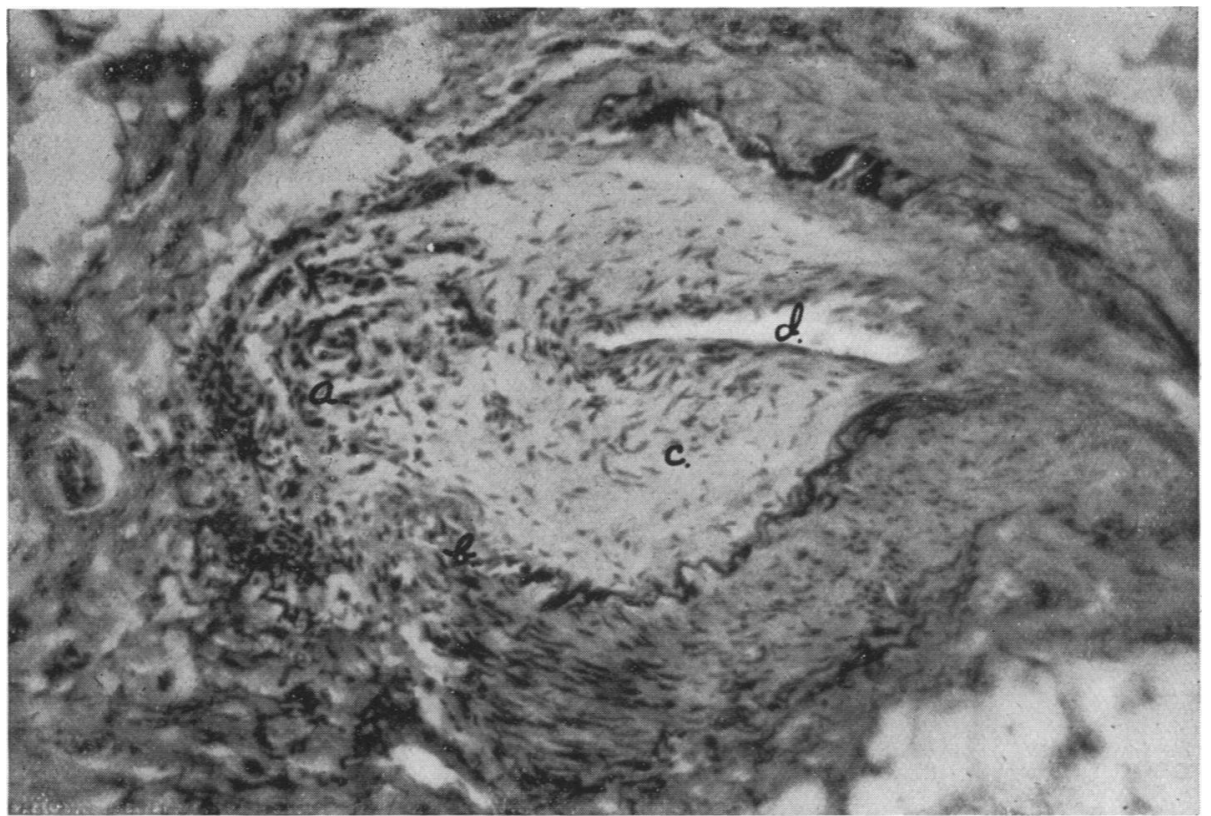

Fig. 1.- Synovial artery showing (a) granulomatous stage of arteritis with (b) disruption of elastic lamina, (c) reactive intimal thickening, and (d) encroachment upon vessel lumen. (Elastic Van Geison.)

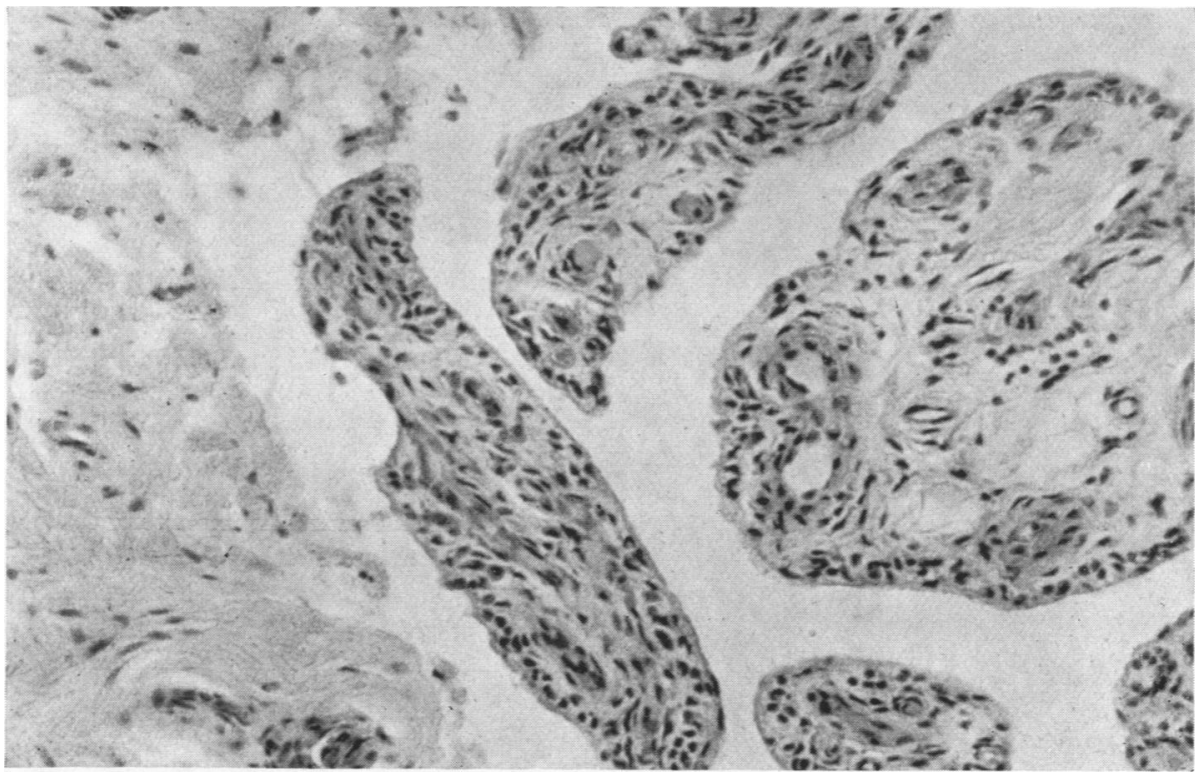

FIG. 2.-Synovial villi, showing mild interstitial oedema and moderate increase in fibroblastic activity. (Haematoxylin and eosin.)

is therefore of the greatest importance, especially in those early cases wherein the neuromuscular system changes may be the only manifestations to assist diagnosis. 


\section{Conclusions}

(1) Tender, aching muscles and arthralgias are common early manifestations of periarteritis nodosa. These become worse with activity, improve with rest, and differ clinically from fibrositis.

(2) Synovial vascular changes are identical with those seen elsewhere in the disease, but synovitis of a grossly demonstrable degree is infrequent; when it occurs, it assumes a less important part in the more profound pathological picture.

(3) Muscle tenderness and arthralgias are commonly the prodromata of a more ominous peripheral neuropathy.

\section{Summary}

Forty-three cases of periarteritis nodosa have been reviewed and the joint and muscle manifestations evaluated.

In thirty (70 per cent.) of the cases, muscle and joint symptoms were the early complaints. In only four cases, however, was there objective evidence of synovial involvement and in no case was joint involvement a major aspect of the clinical picture. Histological study of synovia showed arterial involvement identical to that seen elsewhere in the disease, with spotty synovial change secondary and proportionate to arterial involvement.

Muscle tenderness and aching were common early manifestations, but in only one case were the symptoms suggestive of fibrositis, the muscle symptoms being worse with activity and better with rest. In nineteen cases, there was progression to frank peripheral neuritis.

\section{REFERENCES}

Bauer, W. (1941). New Engl. J. Med., 225, 418.

Boyd, L. J. (1938). Bull. N.Y. med. Coll., 1, 219.

- (1940a). Ibid., 3, 32.

(1940b). Ibid., 3, 272.

Carr, J. G. (1930). Med. Clin. N. Amer., 13, 1121.

Cohen, M. B., Kline, B. S., and Young, A. M. (1936). J. Amer. med. Ass., 107, 1555.

Curtis, A. C., and Coffey, R. M. (1934). Ann. intern. Med., 7, 1345.

Diaz-Rivera, R. S., and Miller, A. J. (1946). Ibid., 24, 420.

Dunbar, J. C. (1936). Bull. Sch. Med., Maryland, 20, 138.

Friedberg, C. K., and Gross, L. (1934). Arch. intern. Med., 54, 170.

Harris, A. W., Lynch, G. W., and O'Hare, J. P. (1939). Ibid., 63, 1163.

Hench, P. S., Bauer, W., Dawson, M. H., Hall, F., Holbrook, W. P., Key, J. A., and McEwen, C. (1940). Ann. intern. Med., 13, 1655.

— - — - Boland, E., Dawson, M. H., Freyberg, R. H., Holbrook, W. P., Key, J. A., Lockie, L. M., and McEwen, C. (1941). Ibid., 15, 1002.

Jones, G. M. (1942). Ibid., 16, 920.

Keefer, C. S. (1943). Bull. N. Engl. med. Cent., 5, 25.

Moschowitz, E. (1938). J. Mt Sinai Hosp., 5, 337.

Rich, A. R. (1942). Bull. Johns Hopk. Hosp., 71, 123.

- , and Gregory, J. E. (1943). Ibid., 72, 65.

Spiegel, R. (1936). Arch. intern. Med., 58, 993.

Vining, C. W. (1938). Arch. Dis. Childh., 13, 31.

Weir, D. R. (1939). Amer. J. Path., 15, 79.

\section{Manifestations articulaires et neuromusculaires de la périartérite noueuse}

RÉSUMÉ

On étudia 43 cas de périartérite noueuse et on évalua les manifestations articulaires et musculaires.

Dans 30 cas $(70 \%)$ les symptômes musculaires et articulaires apparurent précocement. Toutefois, dans quatre cas seulement il y eut des preuves objectives d'implication synoviale, et l'atteinte articulaire ne constitua jamais l'aspect majeur de l'image clinique. L'étude histologique de la 
synoviale montra que l'atteinte artérielle y était identique à celle observée ailleurs au cours de la maladie, avec des modifications synoviales d'aspect tacheté, secondaires, et proportionnelles à l'atteinte artérielle.

La sensibilité musculaire et la douleur constituaient des manifestations précoces communes, mais dans un cas seulement il y avait des signes indiquant une fibrosite, les symptômes musculaires étant plus accentués au mouvement et s'améliorant au repos. Dans 19 cas il y avait une évolution franche vers la névrite périphérique.

\section{Manifestaciones articulares y neuromusculares de la periarteritis nodosa}

\section{SUMARIO}

Cuarenta y tres casos de periarteritis nodosa fueron revisados y sus manifestaciones articulares y neuromusculares valoradas.

En 30 casos (70 por ciento) los síntomas musculares y articulares se manifestaron precozmente. Sin embargo, en cuatro casos solamente hubo pruebas objetivas de la implicación de la sinovia y en ningún caso la afección articular constituyó un aspecto mayor del cuadro clínico. El estudio histológico de la sinovia mostró alteraciones arteriales idénticas a las encontradas en otras partes en esta enfermedad, con el aspecto moteado secundario y proporcional a la implicación arterial.

La sensibilidad y el dolor muscular constituían manifestaciones tempranas comunes, pero en un caso sólo había síntomas indicando una fibrositis, los síntomas musculares siendo peores con actividad y mejores con reposo. En 19 casos hubo evolución franca hacia una neuritis periférica. 